\title{
PORTFOLIOS AS ALTERNATIVE ASSESSMENT STRATEGY FOR ENVIRONMENTAL EDUCATION IN PRE-SERVICE TEACHING EDUCATION AT UNIVERSITY LEVEL
}

\author{
M.Sc. Alejandrina Mata Segreda ${ }^{1}$
}

\begin{abstract}
This article describes the development of the portfolio assessment technique as a strategy for teacher education at university level, in order to create a positive relationship between humans and environment. It shows the theorist approach and the research process used to validate the ground hypothesis. As a result, we found that this strategy stimulates the capacity for self-evaluation, empowers students to act responsibly towards the environment, and helps them develop skills for applying environmental knowledge, even though the performance of the students that participated on the experimental design had no statistic significance. Furthermore, it describes a specific experience in order to facilitate the implementation of the strategy by university faculty in any discipline.
\end{abstract}

Palabras clave: ENVIRONMENTAL EDUCATION/ ASSESSMENT PORTFOLIOS/ COLLEGE EDUCATION

Resumen: Este artículo describe el desarrollo de la técnica de la evaluación del portafolio como estrategia para la educación del profesor en el nivel universitario, para crear una relación positiva entre los seres humanos y el ambiente. Demuestra el acercamiento teórico y el proceso de la investigación usados para validar la hipótesis de tierra. Consecuentemente, encontramos que esta estrategia estimula la capacidad para la autoevaluación, autoriza a estudiantes para actuar responsablemente hacia el ambiente, y les ayuda a desarrollar las habilidades para aplicar conocimiento ambiental, aunque el funcionamiento de los estudiantes que participaron en el diseño experimental no tenía ninguna significación de la estadística. Además, describe una experiencia específica para facilitar la puesta en práctica de la estrategia por la facultad de la universidad en cualquier disciplina.

Palabras clave: EDUCACION AMBIENTAL/ EVALUACION POR PORTAFOLIOS/ ENSEÑANZA SUPERIOR/

\section{What We Did}

A portfolio is a purposeful collection of student work that exhibits the student's efforts, progress and achievements in one or more areas. The collection must include student participation in selecting contents, the criteria for selection, the criteria for judging merit, and evidence of student self-reflection. Even though this technique is not common at the university level, its potential has been proven at other levels. Our interest was to study it with a clear purpose: to promote in teaching students the integration of knowledge, abilities and skills for the action in order to develop a better relationship between humans and the

\footnotetext{
1 Magister Scientiae en Educación de Adultos de la Universidad de Costa Rica. Diploma Estudios Avanzados del Programa de Doctorado en Educación Comparada de la Universidad Nacional de Educación a Distancia, España. Actualmente es Vicerrectora de Vida Estudiantil, ha sido profesora de la Escuela de Orientación y Educación Especial de la Universidad de Costa Rica. Integrante de la Comisión Interuniversitaria de Educación Ambiental (CONARE). e-mail: amatas@cariari.ucr.ac.cl
}

Artículo recibido: 16 de setiembre, 2003

Aprobado: 24 de noviembre, 2003 
environment. Along with this technique, five others were proven within the same research process and by the same research team: controversy generation, concept maps, community work, research project and virtual classroom (Mata et. al, 2003). My interest in this occasion is to expand the research relating to portfolios, my direct responsibility, leaving the results of the other techniques for a later time.

Based on Caduto (1985), this research is important because the groups that contribute to individual education and development in search for a morality and solidarity to others and the environment include parents, families and teachers. Environmental Education is one of the most important tools for making the acquisition of values and responsible behaviors towards conservation and sustainable development possible. There is a mayor probability of successful children education in terms of environmental responsibility, if teachers already posses an appropriate attitude toward environment and act in class accordingly.

In Costa Rica, state universities have been developing important actions to impact the education of future professionals with an environmentally friendly point of view, in order to help them find ways to contribute to the sustainable development of the society, as workers with the power of knowledge and the responsibility to make decisions and mark a path for human wellness. Teachers are perceived by university authorities as the group of professionals that have the most important role in improving the relationship between humans and environment. As a main task of a special team created among the four state universities of the country in 1994 (Comisión Interuniversitaria de Educación Ambiental, CIEA), teacher pre-service education has to be improved with an environmental perspective based on research. Product of a strategic alliance with a Central American organization (Coordinación Educativa y Cultural de Centroamérica, CECC), this research project was developed in 20012002 and its results have been spreading among pre-service teacher education institutions of the region since. The results related to portfolio assessment are going to be presented in this paper.

\section{What is the Theoretical Foundation}

Teacher pre-service education is considered as the stage of the professional development in which the student acquires the cultural, psycho-pedagogical and personal knowledge to cope with the educational tasks and all their complexities, justifying her actions in valid theoretical principles (Imbernón, 1994). What we must look for is the education of future teachers with 
solid theoretical perspectives that enrich the practice by analyzing the educative act, student necessities and their context, and historical perspective of society, in order to recognize change and respect differences. Because of the contextual and historical conditions mentioned before, Environmental Education must be seen as a dimension of the curriculum to promote values and behaviors to help teachers establish a constructive relationship with environment, and promote the same in their students. As a basis of conceptual and methodological articulation, Environmental Education is the meeting point of natural and social sciences where ideas and facts related to human responsibility toward the environment acquire new and constructive meanings (González-Gaudiano, 1998).

One way to implement the environmental dimension in the curriculum is the use of pedagogical strategies in the classroom incorporating this vision. A teaching-learning strategy is a group of relations given or made real in class under the responsibility of the teacher by creating, stirring up, enlightening and conducting conscious actions using a clear didactic methodology, to facilitate the development of the learning process (Blázquez \& Domínguez, 1999). A strategy suggests a logical and coherent organization of contents and resources for teaching, using techniques that respond to an unique philosophy and to a specified learning necessity. In this specific case, innovation is the key ingredient because the transmission of environmental information is not enough. The construction of responsible behaviors towards environment is also needed. An innovation is characterized by pertinent answers to quests, dysfunctions or necessities, considering history, space and time (Dobles, 2001), to promote responsible behaviors toward environment.

With all these conditions in mind, portfolio assessment was considered not a technique but a teaching-learning strategy when used as part of a whole teaching-learning process. This strategy is presented below.

\section{Why is Portfolio Assessment a Strategy for Teaching and Learning}

In adulthood, self-evaluation plays an important role in motivation for learning (Wlodkowski, 1985). Assessment gives an understanding of self-achievement and promotes more involvement in learning. Adults have a clear and specific goal when they study, so it is very important that they collect first hand criteria to encourage motivation through the formal and non-formal education processes. University students are subjects of formal education 
processes, but in addition, they need to feel that the formal plan has a meaning and a purpose for their development as future professionals.

Portfolio assessment is considered a non-traditional technique of evaluation. It consists in making a personal file where the student shows the evidence of her own conceptual construction, her abilities and skills, her motivations for acting, giving special emphasis on accomplishments and mistakes. It is seen as a personal album or a kind of scrapbook where the learner decides what to include, what emphasis to give to each entry, and the value she gives to any elaborated knowledge. Mac Donald and Healy (1999) indicate that it is important to understand that portfolios are not just work folders, random collections of work a student has done, but a complex and comprehensive view of student performance within context. We have a portfolio when the subject of evaluation participates or is responsible for its construction. When evaluating learning, tests are just an instant picture of one single moment. Meanwhile, portfolios can be considered as instruments that complement and enrich the educational process, because they give a direct assessment of student performance and they validate common evaluation (Salvia \& Ysseldike, 1995).

Going beyond its use as an assessment technique, portfolios can be used as a strategy for teaching and learning when they become the heart of the process of education. This means that the students center the planning of a university course on the construction of portfolios in order to collect, understand, select, share and apply knowledge and not to merely demonstrate what he or she has learned. In order to stimulate significant learning, portfolios can become strategies for teaching and learning to help the learners solve problems, absorb new data and make it part of their background. Portfolios become an instrument for evaluation as for learning.

\section{How Portfolios Can Be Used with College Students with Environmental Purposes}

Some assumptions were made for the application of portfolios as strategy for teaching and learning in pre-service education for teachers.

1. To start a portfolio, the only requirement needed is to state an environmental problem with which one wants to work, related to the subject matter of the course. At first, this may look a little bit difficult, but it is possible. A Literature teacher can wonder. What does Literature have to do with the environment? Humanity has 
always worshiped Nature using poetry, tales or novels. Thus, students could make a portfolio that collects examples of these pieces as well as creative writing strategies related to environmental themes to be used in class with children. A Curriculum teacher may wonder how she can integrate environment to her classes without neglecting her theory. One of the main sources of curriculum is the environment. This teacher can ask her students "Can you identify the different values concerning the environment in curriculum?" "How can you design an environmentally oriented educational plan? What resources can you use as a teacher to have an environmentally responsible classroom?" All this knowledge can be organized in portfolios. When evaluating and grading students, pre-service teachers can learn to create tests to identify environmental attitudes, behaviors and knowledge, and can learn to use alternative assessment strategies with children, such as portfolios.

2. Portfolios can be used with groups or with single students at university level. It is necessary for the student who builds a portfolio to interact with somebody, either the professor or the classmates, in order to enrich her appreciations, to put them on perspective, and to facilitate more meaningful knowledge. And sometimes a whole group can make one single portfolio, a very rich experience because beyond the learning of specific concepts, the students can develop more meaningful and collective knowledge related to the shared responsibility of all humans toward the planet.

3. A portfolio is made using a wide variety of techniques to fit individual differences and to give the opportunity to express oneself. Drawing, collage, origami, crafts, sculpture, literature, essays, poetry, music, videos, monographic works, definitions, questions and answers, among other techniques, can be used to build the personal portfolio. The only requirement is to send a clear message to the others in order to stimulate interaction.

4. Each portfolio must receive constant feedback from the professor in order to guarantee its double function: assessment and learning. Because of this, the professor must use time from the lessons to analyze what is happening with the making of portfolios and what knowledge has been achieved by the students. Another thing the professor can do is systematize the input that appears in the portfolios and share them with the classroom every once in a while. 
5. But more importantly, the author of each portfolio must be able to say what she has learned, what the meaning of each entry is, an how she can take control of her own development. This requires a different vision from the university professor because, what is given at the beginning of the course as a basic orientation for the making of the portfolios is what must be taken for the evaluation of the job the student has done. Because this is a qualitative strategy of assessment, the identification of what the student has learned has to be done applying emics and ethics rationality.

6. The use of portfolios as qualitative assessment strategies has to be consistent with the methodology that is applied in the classroom. Both (assessment and methodology) are based on humanistic education conceptions in search of the development of the student in all the areas of her life, and having an active role in driving or leading the process of education.

7. When planning the course with this strategy, it is necessary to integrate teaching and assessing in the same plan. Both processes stimulate learning unlike other quantitative assessment techniques.

\section{How the experiment was carried out}

As stated in the beginning, our interest was to know how useful some environmental educative strategies were in promoting in teaching pre-service students the integration of knowledge, abilities and skills in order to develop a better relationship between humans and the environment. With this problem in mind, we selected two groups of the class Music and Scenic Arts (Universidad Nacional), one as the experimental and the other as the control group. We planned to develop an evaluative research of the application of assessment portfolios, in order to identify and measure the effects of this strategy by comparing them with the proposed goals (Weiss, 1987). The other class was Pedagogy and Technology (Universidad de Costa Rica), with only one group (pre-experimental design), but with the same problem in mind.

Facing the concrete reality of social research that defines a social researcher as a person open to the multi dimensionality of the object of study, it was necessary to collect and analyze data using different sources, and quantitative and qualitative techniques in order to have a complementary approach (Ortí, 1994). That is why we choose as subjects pre-service teaching students and their teachers, and we used a test, a research interview and the papers elaborated by the students, as information sources. We applied an experimental 
design for analyzing statistical inferences with the $t$-Test, and a qualitative design using the Q-Analysis.

The dependent variable was defined as the integration, made by the pre-service teaching students, of knowledge, abilities and skills to increase the ability to generate and facilitate educative actions to promote a better relationship between humans and environment. According to Negra \& Manning (1997), the behaviors and believes of a person reflect the educational experiences to which this person has been exposed. An environmentally responsible behavior is the product, among others, of educational strategies that promote the integration of knowledge, values, attitudes and actions related with the solving of environmental problems. We believe that the most beneficial use of this kind of strategies in the formal training of pre-service teachers, is when they are inserted within the curriculum, when they are not just didactic strategies but part of the structure of the educational programs, as a dimension that is reflected in every curricular component. As stated earlier, a teaching-learning strategy suggests a logical and coherent organization of contents and resources for teaching, using techniques that respond to a unique philosophy and to a specified learning necessity.

To measure this variable, a test was created to be applied before and after the experiment to the pre-service teaching students (both experimental and control groups, and to the preexperimental group), based on the work of Hungerford \& Volk (1990), who elaborated a chart of variables, constitutive definitions, operational definitions and levels of empowerment related to environmental responsible behavior. The three levels of commitment are entrance, appropriation and empowerment, through seven learning actions: environmental sensitivity, knowledge of environmental issues, personal commitment with environmental issues, knowledge of strategic actions for the environment, capacity for the use of these strategies, locus of control and intention for the action. From the qualitative point of view, this variable was searched through the perception the professors construct about their student's class performance. Using a research interview, professors were asked if the application of portfolios as a teaching learning strategy in their experimental classes contributed to the development of skills for solving environmental problems, increase their capacity to construct new environmental knowledge, help them evaluate their own environmental behaviors, let them identify new responsible behaviors, and help them understand what to do in the near future with their own students at school. 
The independent variable was the portfolio assessment strategy, understood as a group of relations given or made real in class under the responsibility of the teacher by creating, stirring up, enlightening and conducting conscious actions using a clear didactic methodology, to facilitate the development of capacities in the students to analyze, auto evaluate and apply knowledge for the solving of environmental problems.

\subsection{An acoustic portfolio.}

It must be remembered that from the course of Music and Scenic Arts there were two groups; one was treated as the control group (did not use the strategy), and the other was used as the experimental group. As part of the program, the issue of "acoustic ecology" has to be studied, a matter of concern in schools because of noise pollution caused by inappropriate didactic techniques and poor management of time and resources in class. According to the professor's binnacle, the strategy was applied with the experimental group, during four lessons (one month). During the first lesson, they talked about the importance of sound and the problems of noise in schools, and share some readings about Environmental Education. They all went for a walk around the university buildings, and "collected" the sounds and noises that could interfere with the appropriate development of classes. During the second lesson, the students showed their findings and started an "acoustic portfolio" using any material they wanted to include (recordings, writings, pictures). What they had to do was to go beyond the description of the problem by creating alternatives for solving it. During the next two lessons, they analyzed every input of the portfolios in order to understand the individual and group perceptions, and to enrich the contents of each portfolio. At the end of the activity, they shared their "learned lessons", and together built a recollection of tips, hints and answers to be used in their practice. It is important to state that this theme was not the only aspect developed in the lessons; in addition to the construction of the personal portfolios, the students continued studying the program of the course. Because they were participating in an experiment, the portfolios were not used as a means to grade students.

\subsection{A virtual porfolio.}

As a case study, in the class of Pedagogy and Technology, the professor decided to apply the strategy throughout the entire course, and used portfolios for grading the students. The purpose of this class was to help the pre-service teaching students apply common software and computational resources (Power Point, Word, Excel, Paint, Publisher, Microworlds, e mail and Internet), to school. The whole course consisted in the construction of a virtual portfolio 
where each student showed all the options they constructed for the application of the different tools, reporting the personal interpretation of the ground theory, the applications in the elementary class, and other considerations regarding the potential of computers in the classroom. The theme of every application was the environment. The students searched for environmental information through the Internet, shared with the classmates some of it through e-mail, created environmental explanations using Power Point, wrote about environmental education using the Word processor, create environmental signals and brochures with Publisher, among other things. Every once in a while, the professor reviewed the virtual portfolios saved in specific folders, and emailed the class his impressions about the work the students were doing.

\section{What were the results}

We used descriptive and inferential statistics for the quantitative part of the experiment. The participants of the course Music and Scenic Arts were 20 students in the control group and 23 in the experimental group. They were all women, and the $72 \%$ of them were between the ages of 19 and 22. At the beginning of the experiment, when the pretest was applied, the results showed that both the students of the control and experimental groups had a poor performance related to their environmental commitment. All of them belonged to the entrance and appropriation levels of commitment, and from the seven learning actions, they showed management of only the first three of them. The average grading for the students of the experimental group on the posttest was 12 points above the average of the control group, a small difference because the total possible grading of the test was 336 points. This means that at the end of the experiment, both groups showed a similar increase in their intention to be environmentally responsible. But it is important to point out that the increase in the control group is seen at only one category, "knowledge about environmental issues", and the experimental group shows its increase in two categories, "knowledge about environmental issues", and "personal commitment to solving environmental problems". According to the theory used for this research, the learning of responsible environmental actions related (how to solve problems) is more important than the learning of detecting environmental problems. The results of the $t$ Test confirm what it was seen on the descriptive results, that is, that both groups showed an increase above $10 \%$ on the statistical significant level, but with no important differences among them. 
The qualitative evaluation of the strategy's application shows results of other category that better explain what was seen inside the grading of the test after the experiment concluded. As stated above, we used the approach of content analysis applying the Q-Analysis technique. We searched for relationships inside the text collected with the research interview. In this case, the professor was interviewed following a simple guide that included questions regarded his opinion about the student reactions, whether or not he could see a different rhythm or quality in the students' learning process, how the students focused on environmental problems, whether or not they had a positive attitude toward the strategy, and the giving of examples to corroborate his opinions, among others. Another source of information were 5 from the 23 portfolios made by the students, chosen randomly. When we organized and analyzed these information, some theoretical facts were seen as effects that were expected from the application of the portfolio assessment strategy, elements that became the objects of the learning process. What was learned by the students, according to the professor's point of view and the portfolios, became the vehicles that made the learning process possible. By comparing and engaging these two types of knowledge constructed by students, a learning structure was drawn and its analysis told us how intense the teaching and learning process were. What we found was that on the experimental group, three objects were clearly identified: the development of the ability to apply environmental knowledge, the increase of the ability for auto-evaluating one's own learning process, and the empowerment for responsible environmental actions. These objects were engaged or tied by five vehicles: assessment mechanisms; social, psychological and cultural perspective; environmental knowledge, abilities and skills; environmental values, attitudes and behaviors; and consciousness of the one's own learning process.

It must be remembered that we used a pre-experimental design with the course of Pedagogy and Technology because this was treated as a case study. The students were 15 women and 3 men, $50 \%$ of them between the ages of 19 and 21. The pretest showed a poor performance of the students of this group, because they were on the entrance and appropriation level of commitment, and on the three first categories of learning actions. An increase of about $20 \%$ on the average of the test was observed between pre and posttest. Furthermore, at the pre test, $11 \%$ of the students were on the category of "environmental sensitivity", and $61 \%$ on the category of "knowledge about environmental issues". At the posttest, no one remained on the first category, $31,25 \%$ stayed on "knowledge about environmental issues", 56,25\% moved on the next category, "personal commitment to solving 
environmental problems", and 12,50\% reached "knowledge of strategic actions for the environment". The improvement of the students was evident because the levels of commitment showed an important variation between the pre and posttest: at the beginning, all of them were at the entrance and appropriation levels, and at the end, no one remained on the first one, and two students went to the superior level, the empowerment. We did not apply qualitative assessment to the case study.

\section{What we can conclude}

1. The application of portfolio assessment as an experimental design to the course Music and Scenic Arts did not give statistical significant results, but practical significant results. The students of both groups showed a similar improvement in their environmental responsible behavior after the experiment, but the quality of their learning was different because an important number of students of the experimental group went up one category of learning actions.

2. The application of portfolio assessment as a case study to the course of Pedagogy and Technology gave statistical significant results, even though the results can not be generalized to the whole population. The students showed an important increase on the posttest in both grading criteria: the levels of commitment and the categories of learning actions.

3. One element that could influence the results is time. When the strategy was used for one month, the improvement on the quality of the students' learning process was poor, but when it was used for a semester, the students showed a better performance in class. This conclusion must be seen as a hypothesis because of the nature of both experiences (one was experimental and the other was pre experimental).

4. Another element that could affect the results is the role of the strategy into the course. In the first case, the strategy was applied on one theme of the course, and in the second, it was applied as the main structure of the course. This conclusion must be seen as a hypothesis too, because of the same reasons.

5. In the case of the experimental design, the use of results from both perspectives, quantitative and qualitative, enriched the analysis because test results were better explained. As social researchers, we have to understand this phenomena beyond the simple description of it, to make adequate interpretations that help find adequate solutions to problems. The quality of the knowledge constructed by the students of 
this group, even though the evidence shows just a small improvement, could be enhance with a more structured and conscious process of educational planning.

6. As a special call for attention, it is important to analyze the performance of the students on the pretest. Even though Costa Rican state universities have made important efforts to implement Environmental Education into the curriculums, the results in this case are not satisfactory. Of the three levels of involvement (entrance, appropriation and empowerment), students were only involved with the first two of them. From the seven learning actions (environmental sensitivity, knowledge of environmental issues, personal commitment with environmental issues, knowledge of strategic actions for the environment, capacity for the use of these strategies, locus of control and intention for the action), students showed an adequate management of only the first three of them.

7. This experience suggests that it is necessary to make a strategic planning of the efforts related with Environmental Education in pre-service teaching education. Isolated actions may not be worth the effort, even though they are good efforts. The inclusion of environmental teaching and learning strategies every once in a while do not make a real difference. It has to be a consistent action in order to impact efficiently and effectively the education of future professionals in the field of Education.

\section{References}

Blázquez, Florentino \& Domínguez, M.A. (1999). Focos conceptuales para la formación inicial del profesorado de educación secundaria. Educación XXI (2): 155-182.

Caduto, M. (1985) A Guide for Environmental Values. UNESCO-UNEP International Environmental Education Program: Environmental Education. Serie 13.

Dobles, María C. (2001). Características de las innovaciones educativas. San José, Costa Rica: Fundación Omar Dengo (material mimeografiado).

González-Gaudiano, Eduardo (1998). Centro y periferia de la Educación Ambiental. Un enfoque antiesencialista. México: Mundi Prensa México.

Hungerford, H. \& Volk, T. (1990). Changing Learner Behavior Through Environmental Education. The Journal of Environmental Education. 21(3); 8-21.

Imbernón, Francesc (1994). La formación y el desarrollo profesional del profesorado. Barcelona: Graó. 
Mata, Alejandrina; Zúñiga, Claudia; Brenes, Olga E.; Carrillo, María A.; Charpentier, Claudia; Hernández, Lidia M. \& Zúñiga, María E. (2003) Estrategias innovadoras para la formación inicial de educadores en el campo ambiental. San José: Coordinación Educativa y Cultural Centroamericana.

Mc. Donald, Robert E. \& Healy, Seán D. (1999). A Handbook for Beginning Teachers. New York: Longman.

Negra, C. \& Manning, R.E. (1997). Incorporating Environmental Behavior, Ethics and Values into Nonformal Environmental Educational Programs. The Journal of Environmental Education. 28(2): 10-21.

Ortí, Alfonso. (1994). La confrontación y niveles epistemológicos en la génesis e historia de la investigación social. Métodos y técnicas de investigación en Ciencias Sociales. Madrid: Síntesis Psicología.

Salvia, J. \& Ysseldike, J.E. (1995). Assessment. Boston: Houghton Mifflin.

Weiss, Carol. (1987). Investigación evaluativa. México: Trillás.

Wlodkowski, Raymond J. (1985). Enhancing Adult Motivation to Learn. San Francisco, USA: Jorsey-Bass Publishers. 